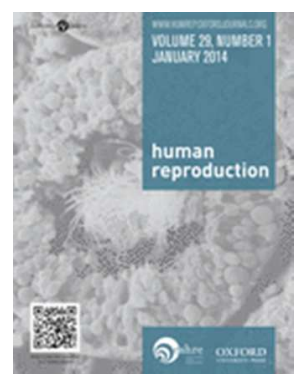

Draft Manuscript For Review. Reviewers should submit their review at http://mc.manuscriptcentral.com/humrep

\title{
ESHRE guideline: Management of women with premature ovarian insufficiency (POI)
}

\begin{tabular}{|c|c|}
\hline Journal: & Human Reproduction \\
\hline Manuscript ID & HUMREP-15-1399 \\
\hline Manuscript Type: & ESHRE pages \\
\hline Date Submitted by the Author: & 14-Dec-2015 \\
\hline Complete List of Authors: & $\begin{array}{l}\text { the ESHRE Guideline Group on POI, xx; ESHRE } \\
\text { Webber, Lisa; University College London Hospital } \\
\text { Davies, Melanie; UCLH Foundation Trust, Reproductive Medicine Unit } \\
\text { Anderson, Richard; University of Edinburgh, MRC Centre for Reproductive } \\
\text { Health } \\
\text { Bartlett, Jane; The Daisy Network } \\
\text { Braat, Didi; Radboudumc Nijmegen } \\
\text { Cartwright, Beth; ST5 Obstetrics and Gynaecology trainee LondonKSS } \\
\text { Cifkova, Renata; Center for Cardiovascular Prevention, Charles University } \\
\text { in Prague, First Faculty of Medicine and Thomayer Hospital } \\
\text { de Muinck Keizer-Schrama, Sabine ; Erasmus University Medical Center } \\
\text { Rotterdam } \\
\text { Hogervorst, Eef; Applied Cognitive Research (SSEHS) } \\
\text { Janse, Femi; University Medical Center Utrecht, Department of } \\
\text { Reproductive Medicine and Gynaecology } \\
\text { Liao, Lih-Mei; The Middlesex Clinic, Unversity College Hospital, London } \\
\text { Vlaisavljevic, Veljko; University Medical Centre Maribor } \\
\text { Zillikens, Carola; Erasmus University Medical Center Rotterdam } \\
\text { Vermeulen, Nathalie; ESHRE, }\end{array}$ \\
\hline Keywords: & $\begin{array}{l}\text { premature ovarian insufficiency, POI, European Society of Human } \\
\text { Reproduction and Embryology, guideline, evidence based }\end{array}$ \\
\hline Specialty: & Reproductive Endocrinology \\
\hline
\end{tabular}


Title:

ESHRE guideline: Management of women with premature ovarian insufficiency (POI)

Authors:

The ESHRE Guideline Group on POI

L. Webber

M. Davies

R. Anderson

J. Bartlett

D. Braat

B. Cartwright

R. Cifkova

S. de Muinck Keizer-Schrama

E. Hogervorst

F. Janse

L. Liao

V. Vlaisavljevic

C. Zillikens

N. Vermeulen 


\section{Corresponding author}

L. Webber

Word count

Abstract: 361 words

Text (excluding abstract, acknowledgments, figure legends, and references): 3995 words

Number of tables: 3

\section{Declaration of authors' role:}

LW chaired the guideline development group and hence fulfilled a leading role in collecting the evidence, writing the manuscript and dealing with reviewer comments. NV, as methodological expert, performed all literature searches for the guideline, provided methodological support and was overall coordinator of the guideline production. MD was co-Chair of the guideline development group until December 2014. JB represented the patient perspective in the guideline group. All other authors, listed in alphabetical order, as guideline group members, contributed equally to the manuscript, by drafting key questions, synthesising evidence, writing the different parts of the guideline and discussing recommendations until consensus within the group was reached.

\section{Conflicts of interest}

DB reports research grants from MSD, Ferring and Serono. The other authors reported no conflicts of interest.

\section{Acknowledgements}

The Guideline development group would like to thank invited experts Frank Broekmans, Gerard Conway, Alberto Falorni, Angela Maas and Anette Tonnes Pedersen for providing helpful comments as experts on specific areas of this multidisciplinary guideline. The guideline development group also acknowledges the help of many clinicians and patient organisations who refereed the content of the Guideline. 
Funding

The study has no external funding; all costs are covered by ESHRE.

Key words

premature ovarian insufficiency, POI, European Society of Human Reproduction and Embryology, guideline, evidence based 


\section{Abstract}

Study question: What is the optimal management of women with premature ovarian insufficiency based on the best available evidence in the literature?

Summary answer: The guideline development group formulated 99 recommendations answering 31 key questions on the diagnosis and treatment of women with premature ovarian insufficiency.

What is known already: NA

Study design, size, duration: This guideline was produced by a multidisciplinary group of experts in the field using the methodology of the Manual for ESHRE Guideline Development, including a thorough systematic search of the literature, quality assessment of the included papers up to September 2014 and consensus within the guideline group on all recommendations. The guideline development group included a patient representative to ensure input from women with POI. After finalisation of the draft, ESHRE members and professional organisations were asked to review the guideline.

Participants/materials, setting, methods: NA

Main results and the role of chance: The guideline provides 17 recommendations on diagnosis and assessment of $\mathrm{POI}$ and 46 recommendations on the different sequelae of $\mathrm{POI}$ and their consequences for monitoring and treatment. Furthermore, 24 recommendations were formulated on hormone replacement therapy in women with $\mathrm{POI}$, and 2 on alternative and complementary treatment. A chapter on puberty induction resulted in 5 recommendations.

Limitations, reasons for caution: The main limitation of the guideline is that due to the lack of data, many of the recommendations are based on expert opinion, or indirect evidence from studies on postmenopausal women or women with Turner Syndrome, were possible.

Wider implications of the findings: Despite the limitations, the guideline group is confident that this document will be able to guide health care professionals in providing the best practice for managing women with POI given current evidence. Furthermore, the guideline group has formulated research recommendations 
on the gaps in knowledge identified in the literature searches, in an attempt to stimulate research on the key issues in POI.

Study funding/competing interest(s): The guideline was developed and funded by ESHRE, covering expenses associated with the guideline meetings, with the literature searches and with the implementation of the guideline. The guideline group members did not receive payment. All guideline group members disclosed conflicts of interest.

Trial registration number: NA 


\section{Introduction}

This ESHRE guideline on the management of women with premature ovarian insufficiency offers best practice advice on the care of women with premature ovarian insufficiency, both primary and secondary. The patient population comprises women younger than 40 years (which includes Turner Syndrome patients) and women older than 40 years, but with disease onset before 40 .

Furthermore, this clinical guideline provides recommendations on the initial assessment and management of women with premature ovarian insufficiency. The initial assessment includes diagnosis, assessment of causation, and basic assessment. The management includes hormonal treatment. Since POI has consequences for health apart from gynaecological issues, these are also described. Consequences of POI and treatment options are included in the following domains: fertility and contraception, bone health, cardiovascular issues, psychosexual function, psychological function, and neurological function.

Other topics discussed are puberty induction, life expectancy, and implications for relatives of women with POI.

This guideline is limited to POI and does not apply to women with low ovarian reserve. 
1

2

3

4

\section{5}

6

7

8

\section{Methods}

The guideline was developed according to a well-documented methodology, universal to ESHRE guidelines (Vermeulen, et al., 2014).

In short, 31 key questions were formulated by the guideline group and structured in PICO format (Patient, Intervention, Comparison, Outcome). For each question we searched the databases (PUBMED/MEDLINE , Cochrane library, Psyclnfo) from inception to 1 April 2014. The literature searches were limited to studies written in English. Based on the evidence, and after constructing evidence tables and quality assessment, draft recommendations were written by the assigned expert guideline group member. Two 2-day meetings were organised to discuss the evidence and recommendations and to reach consensus on the final formulation of the recommendations.

For each recommendation, a grade (A-D) was assigned based on the strength of the supporting evidence (scored from 1++ to 4). In case of absence of evidence, the Guideline Development Group (GDG) could decide on writing good practice points (GPP), based on clinical expertise (see table 1).

After finalisation of the guideline draft, an invitation to review was published on the ESHRE website. In addition, an invitation to review was sent to members of the ESHRE special interest group Reproductive Endocrinology $(n=6000)$ and to professional organisations on human reproduction, gynaecology, endocrinology and menopause $(n=79)$. Three hundred ninety-eight comments from 34 reviewers were processed by the methodological expert (NV) and the chair of the GDG (LW) either by adapting the content of the guideline and/or by replying to the reviewer. The review process was summarized in the review report, published on the ESHRE website.

The guideline will be considered for update 4 years after publication, with an intermediate assessment of the need for updating 2 years after publication. 
Key questions and recommendations

The current document summarizes the key questions and the recommendations for clinical practice. Further background information and the supporting evidence for each recommendation can be found in the full version of the guideline available at http://www.eshre.eu/Guidelines-and-Legal/Guidelines

\section{What should this condition be called?}

Primary ovarian insufficiency was first described in 1942 and has, since then, been described with different names and definitions (Albright, et al., 1942).

The term "premature ovarian insufficiency" should be used to describe this condition in research and clinical practice.

\section{How should POI be defined?}

Premature ovarian insufficiency is a clinical syndrome defined by loss of ovarian activity before the age of 40 .

$\mathrm{POI}$ is characterised by menstrual disturbance (amenorrhea or oligomenorrhea) with raised gonadotropins and low estradiol.

\section{What is the prevalence of Premature Ovarian Insufficiency in the general population?}

The prevalence of $\mathrm{POI}$ is approximately $1 \%$. Population characteristics such as ethnicity may affect the prevalence.

In view of the long-term health consequences of POI, efforts should be made to reduce the incidence of POI. Modifiable factors may include: (1) gynaecological surgical practice, (2) lifestyle - smoking, (3) modified treatment regimens for malignant and chronic diseases.

\section{DIAGNOSIS OF POI}

Summary of diagnostic workup in table 2.

What are the symptoms of Premature Ovarian Insufficiency? 
Clinicians should enquire about symptoms of estrogen deficiency in women presenting with oligomenorrhea or amenorrhea.

POI needs to be excluded in women with amenorrhea/oligomenorrhea or estrogen-deficiency symptoms below the age of 40 years.

What investigations should be performed for diagnosis of premature ovarian insufficiency? biochemical confirmation.

Although proper diagnostic accuracy in POI is lacking, the GDG recommends the following diagnostic criteria: (1) oligo/amenorrhea for at least 4 months, and (2) an elevated FSH level > 25 IU/I on two occasions > 4 weeks apart.

What are the known causes of POI and how should they be investigated?

Chromosomal analysis should be performed in all women with non-iatrogenic Premature Ovarian Insufficiency (Bachelot, et al., 2009, Jiao, et al., 2012, Kalantari, et al., 2013, Rocha, et al., 2011).

Gonadectomy should be recommended for all women with detectable $Y$ chromosomal material (Rocha, et al., 2011).

Fragile-X premutation testing is indicated in POI women (Bachelot, et al., 2009, Genetics Committee of the Society of Obstetricians and Gynaecologists of Canada, et al., 2008).

The implications of the fragile-X premutation should be discussed before the test is performed. 
Autosomal genetic testing is not at present indicated in women with POI, unless there is evidence suggesting a specific mutation (e.g. BPES).

Screening for 210H-Ab (or alternatively adrenocortical antibodies (ACA)) should be considered in women with POI of unknown cause or if an immune disorder is suspected.

Refer POI patients with a positive $210 \mathrm{H}-\mathrm{Ab} / \mathrm{ACA}$ test to an endocrinologist for testing of adrenal function and to rule out Addison's disease (Bakalov, et al., 2002, Chen, et al., 1996, Dal Pra, et al., 2003, Husebye and Lovas, 2009)

Screening for thyroid (TPO-Ab) antibodies should be performed in women with POI of unknown cause or if an immune disorder is suspected.

In patients with a positive TPO-Ab test, thyroid stimulating hormone (TSH) should be measured every year (Goswami, et al., 2006, Hollowell, et al., 2002, Kim, et al., 1997).

There is insufficient evidence to recommend routinely screening POI women for diabetes (Kim, et al., 1997).

There is no indication for infection screening in women with POI (Kokcu, 2010).

The possibility of POI being a consequence of a medical or surgical intervention should be discussed with women as part of the consenting process for that treatment.

Although no causal relation has been proved for cigarette smoking and $\mathrm{POI}$, there is a relation to early menopause. Therefore, women who are prone to POI should be advised to stop smoking.

54 In a significant number of women with $\mathrm{POI}$, the cause is not identified and these women are described as 55 having unexplained or idiopathic POI. 
If 21OH-Ab/ACA and TPO-Ab are negative in women with POI, there is no indication for retesting later in life, unless signs or symptoms of these endocrine diseases develop (Betterle, et al., 1997).

What are the implications for relatives of women with POI?

Relatives of women with the fragile-X premutation should be offered genetic counselling and testing (Finucane, et al., 2012, Genetics Committee of the Society of Obstetricians and Gynaecologists of Canada, et al., 2008).

Relatives of women with non-iatrogenic premature ovarian insufficiency who are concerned about their risk for developing POI should be informed that: (1) currently there is no proven predictive test to identify women that will develop POI, unless a mutation known to be related to POI was detected, (2) there are no established POI preventing measures, (3) fertility preservation appears as a promising option, although studies are lacking, and (4) their potential risk of earlier menopause should be taken into account when planning a family.

\section{What are the consequences of POI for life expectancy?}

Untreated POI is associated with reduced life expectancy, largely due to cardiovascular disease (Amagai, et al., 2006, Hong, et al., 2007, Ossewaarde, et al., 2005, Rocca, et al., 2006, Wu, et al., 2014).

Women with POI should be advised on how to reduce cardiovascular risk factors by not smoking, taking regular exercise, and maintaining a healthy weight.

\section{B}
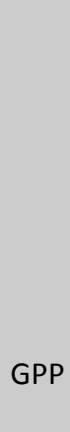
What are the consequences of POI for fertility?

Women with POI should be informed that there is a small chance of spontaneous pregnancy.

Women with POI should be advised to use contraception if they wish to avoid pregnancy.

What fertility interventions are effective?

Inform women with POI that there are no interventions that have been reliably shown to increase ovarian activity and natural conception rates (van Kasteren and Schoemaker, 1999).

Oocyte donation is an established option for fertility in women with POI (Oyesanya, et al., 2009, Sauer, et al., 1994, Sung, et al., 1997, Templeton, et al., 1996).

Inform women considering oocyte donation from sisters that this carries a higher risk of cycle cancellation (Sung, et al., 1997)

In women with established POI, the opportunity for fertility preservation is missed.

A 
Women should be reassured that spontaneous pregnancies after idiopathic $\mathrm{POI}$ or most forms of chemotherapy do not show any higher obstetric or neonatal risk than in the general population (Scottish Intercollegiate Guidelines Network (SIGN), 2013, Signorello, et al., 2012).

Oocyte donation pregnancies are high risk and should be managed in an appropriate obstetric unit. Women and their partners should be encouraged to disclose the origin of their pregnancy with their obstetric team (Abdalla, et al., 1998, Nelson and Lawlor, 2011, Pados, et al., 1994, Soderstrom-Anttila, et al., 1998, Stoop, et al., 2012).

Antenatal aneuploidy screening should be based on the age of the oocyte donor (Bowman and Saunders, 1994, Donnenfeld, et al., 2002).

Pregnancies in women who have received radiation to the uterus are at high risk of obstetric complications and should be managed in an appropriate obstetric unit (Bath, et al., 1999, Larsen, et al., 2004, Scottish Intercollegiate Guidelines Network (SIGN), 2013, Signorello, et al., 2010, Wo and Viswanathan, 2009).

Pregnancies in women with Turner Syndrome are at very high risk of obstetric and nonobstetric complications and should be managed in an appropriate obstetric unit with cardiologist involvement (Bryman, et al., 2011, Hadnott, et al., 2011, Hagman, et al., 2013, Karnis, 2012).

A cardiologist should be involved in care of pregnant women who have received anthracyclines and/or cardiac irradiation (Mulrooney, et al., 2009, Scottish Intercollegiate Guidelines Network D (SIGN), 2013). 
Women presenting for oocyte donation who are suspected of having POI should be fully investigated prior to oocyte donation, including thyroid and adrenal function as well as karyotype (Abdalla, et al., 1998).

Women previously exposed to anthracyclines, high dose cyclophosphamide or mediastinal irradiation should have an echocardiogram prior to pregnancy, and referral to a cardiologist if indicated (Altena, et al., 2012, Bar, et al., 2003, Felker, et al., 2000, Gorton, et al., 2000, van Dalen, et al., 2006). .

Women with Turner Syndrome should be assessed by a cardiologist with a specialist interest in adult congenital heart disease and should have a general medical and endocrine examination.

Women with POI should have their blood pressure, renal function, and thyroid function assessed prior to pregnancy (Haddow, et al., 1999).

Pregnancy in some women can be of such high risk that clinicians may consider oocyte donation to be life threatening and therefore inappropriate.

POI is associated with reduced bone mineral density (BMD) (Bachelot, et al., 2009, Bakalov, et al., 2003, Castaneda, et al., 1997, Conway, et al., 1996, Freriks, et al., 2011, Hadjidakis, et al., 1999, Han, et al., 2008, Michala, et al., 2008, Park, et al., 1999, Popat, et al., 2009, Ratcliffe, et al., 1992).

Reduced $\mathrm{BMD}$ is very likely to indicate that $\mathrm{POI}$ is associated with an increased risk of fracture later in life, although this has not been adequately demonstrated. 
Women should maintain a healthy lifestyle, involving weight-bearing exercise, avoidance of smoking, and maintenance of normal body weight to optimize bone health.

A balanced diet will contain the recommended intake of calcium and vitamin D. Dietary supplementation may be required in women with inadequate vitamin D status and/or calcium intake, and may be of value in women with low BMD (Bours, et al., 2011, Challoumas, et al., 2013).

Estrogen replacement is recommended to maintain bone health and prevent osteoporosis; it is plausible that it will reduce the risk of fracture (Kanis, et al., 2013, Lindsay, et al., 1980, Prior, et al., 1997).

The combined oral contraceptive pill may be appropriate for some women but effects on BMD are less favourable (Crofton, et al., 2010)

Other pharmacological treatments, including bisphosphonates, should only be considered with advice from an osteoporosis specialist. Particular caution applies to women desiring pregnancy (Shapiro, et al., 2011, Stevenson, et al., 2005).

How should bone health be monitored in women with POI?

It is important to consider bone health at diagnosis in POI, and during ongoing care.

Measurement of BMD at initial diagnosis of POI should be considered for all women, but especially when there are additional risk factors (Kanis, et al., 2013).

If $\mathrm{BMD}$ is normal and adequate systemic estrogen replacement is commenced, the value of repeated DEXA scan is low.

If a diagnosis of osteoporosis is made and estrogen replacement or other therapy initiated, BMD measurement should be repeated within 5 years. A decrease in BMD should prompt 
review of estrogen replacement therapy and of other potential factors. Review by a specialist in osteoporosis may be appropriate.

What are the consequences of POI for the cardiovascular system?

Women with $\mathrm{POI}$ are at increased risk of cardiovascular disease and should be advised of risk factors that they can modify through behavioural change (e.g. stopping smoking, taking regular weight-bearing exercise, healthy weight) (Atsma, et al., 2006, Baba, et al., 2010, Cooper and Sandler, 1998, de Kleijn, et al., 2002, Gallagher, et al., 2011, Hong, et al., 2007, Hu, et al., 1999, Jacobsen, et al., 2003, Jacobsen, et al., 2004, Jacobsen, et al., 1999, Lokkegaard, et al., 2006, Mondul, et al., 2005, Perk, et al., 2012, van der Schouw, et al., 1996).

All women diagnosed with Turner Syndrome should be evaluated by a cardiologist with expertise in congenital heart disease (Bondy, 2008, Gravholt, et al., 1998, Sharma, et al., 2009).

Is estrogen replacement cardio-protective?

Despite lack of longitudinal outcome data, hormone replacement therapy with early initiation is strongly recommended in women with $\mathrm{POI}$ to control future risk of cardiovascular disease; it should be continued at least until the average age of natural menopause (Kalantaridou, et al., 2004, Langrish, et al., 2009, Lokkegaard, et al., 2006, Ostberg, et al., 2007). 
Cardiovascular risk should be assessed in women diagnosed with POI. At least blood pressure, weight and smoking status should be monitored annually with other risk factors being assessed if indicated.

In women with Turner Syndrome, cardiovascular risk factors should be assessed at diagnosis and annually monitored (at least blood pressure, smoking, weight, lipid profile, fasting plasma glucose, HbA1c) (Freriks, et al., 2011).

What are the consequences of $\mathrm{POI}$ on psychological wellbeing and quality of life?

A diagnosis of POI has a significant negative impact on psychological wellbeing and quality of life (Liao, et al., 2000, Mann, et al., 2012, Schmidt, et al., 2011).

What are the Management options for reduced quality of life associated with POI?

Psychological and lifestyle interventions should be accessible to women with POI (Boivin, 2003, Duijts, et al., 2012, Mann, et al., 2012).

B

What are the consequences of POI for sexuality?

Routinely inquire about sexual wellbeing and sexual function in women with POI. 
Adequate estrogen replacement is regarded as a starting point for normalising sexual function. Local estrogen may be required to treat dyspareunia (Pacello, et al., 2013, Rubinow, et al., C 1998, Sarrel, 1987).

Women with POI should receive adequate counselling about the possibility of using testosterone supplementation so that they can make an informed choice, in the knowledge that long-term efficacy and safety are unknown (Alexander, et al., 2004, Kingsberg, et al., 2008).

What treatments are available for genito-urinary symptoms in POI?

Local estrogens are effective in treatment of genito-urinary symptoms (Suckling, et al., 2006).

Clinicians should be aware that despite seemingly adequate systemic HRT, women with POI may experience genito-urinary symptoms. Local estrogens may be given in addition to systemic HRT (Pacello, et al., 2013).

Lubricants are useful for treatment of vaginal discomfort and dyspareunia for women not using HRT (Grimaldi, et al., 2012, Le Donne, et al., 2011).

What are the consequences of POI on neurological function?

The possible detrimental effect on cognition should be discussed when planning hysterectomy and/or oophorectomy under the age of 50 years, especially for prophylactic reasons (Bove, et al., 2014, Phung, et al., 2010, Rocca, et al., 2007, Rocca, et al., 2008, Vearncombe and Pachana, 2009). 
Estrogen replacement to reduce the possible risk of cognitive impairment should be considered in women with POI at least until the average age of natural menopause (Bove, et al., 2014, File, et al., 2002, Hogervorst and Bandelow, 2010, Kritz-Silverstein and BarrettConnor, 2002, Phillips and Sherwin, 1992, Sherwin, 1988, Sherwin, 1994).

Women with POI should be advised to take lifestyle measures (e.g. exercise, cessation of smoking, maintaining a healthy weight) to reduce possible risks for cognitive impairment.

Indications for hormone replacement therapy (HRT)

Hormone replacement therapy is indicated for the treatment of symptoms of low estrogen in women with POI (Absolom, et al., 2008, Madalinska, et al., 2006, Piccioni, et al., 2004).

Women should be advised that HRT may have a role in primary prevention of diseases of the cardiovascular system and for bone protection (Kalantaridou, et al., 2004, Kanis, et al., 2013, Langrish, et al., 2009, Lindsay, et al., 1980, Lokkegaard, et al., 2006, Ostberg, et al., 2007, Prior, et al., 1997).

What are the risks of hormone replacement therapy?

Women with POI should be informed that HRT has not been found to increase the risk of breast cancer before the age of natural menopause (Benetti-Pinto, et al., 2008, Soares, et al., D 2010, Wu, et al., 2014).

Progestogen should be given in combination with estrogen therapy to protect the endometrium in women with an intact uterus (Furness, et al., 2012). 
$17-\beta$ estradiol is preferred to ethinylestradiol or conjugated equine estrogens for estrogen replacement (Crofton, et al., 2010, Langrish, et al., 2009).

Women should be informed that whilst there may be advantages to micronized natural progesterone, the strongest evidence of endometrial protection is for oral cyclical combined treatment

103

Patient preference for route and method of administration of each component of HRT must be considered when prescribing, as should contraceptive needs.

Once established on therapy, women with POI using HRT should have a clinical review annually, paying particular attention to compliance.

No routine monitoring tests are required but may be prompted by specific symptoms or concerns. 
Women should be informed that androgen treatment is only supported by limited data, and that long-term health effects are not clear yet (Braunstein, et al., 2005, Buster, et al., 2005, Davis, et al., 2008, Davis, et al., 2006, Panay, et al., 2010, Shifren, et al., 2000, Simon, et al., 2005, Tamimi, et al., 2006)

If androgen therapy is commenced, treatment effect should be evaluated after 3-6 months and should possibly be limited to 24 months.

HRT in POI women with special issues

Girls and women with POI due to Turner Syndrome should be offered HRT throughout the normal reproductive lifespan (Crofton, et al., 2010, Downey, et al., 1991, Elsheikh, et al., 2000, Gravholt, et al., 1998, Khastgir, et al., 2003, Kodama, et al., 2012, Mortensen, et al., 2009, Romans, et al., 1998, Ross, et al., 1998, Swillen, et al., 1993).

111

HRT is a treatment option for women carrying BRCA1/2 mutations but without personal history of breast cancer after prophylactic bilateral salpingo-oophorectomy (BSO) (Armstrong, et al., 2004, Madalinska, et al., 2006, Rebbeck, et al., 2005). 
For women with endometriosis who required oophorectomy, combined estrogen/progestogen therapy can be effective for the treatment of vasomotor symptoms and may reduce the risk of disease reactivation (Dunselman, et al., 2014).

115

116

Migraine should not be seen as a contraindication to HRT use by women with POI.

Consideration should be given to changing dose, route of administration or regimen if migraine worsens during HRT.

Transdermal delivery may be the lowest-risk route of administration of estrogen for migrainesufferers with aura (Nappi, et al., 2001).

117

Women with POI and hypertension

Hypertension should not be considered a contraindication to HRT use by women with POI

In hypertensive women with $\mathrm{POI}$, transdermal estradiol is the preferred method of delivery (Langrish, et al., 2009, White, 2007).

119

Women with POI and a history of prior venous thromboembolism (VTE)

Women with POI and a history of prior venous thromboembolism (VTE) or thrombophilic disorder should be referred to a haematologist prior to commencing HRT.

Transdermal estradiol is the preferred route of delivery for women with POI at increased risk of VTE (Canonico, et al., 2008). 
Transdermal estradiol is the preferred method of delivery for women with POI requiring HRT who are obese or overweight (Canonico, et al., 2006).

Fibroids are not a contraindication to HRT use by women with POI (Ang, et al., 2001, Ciarmela, et al., 2014).

Women with POI should be advised of risk factors that they can modify through behavioural change (e.g. stopping smoking, taking regular weight-bearing exercise, healthy weight).

Women should be informed that for most alternative and complementary treatments evidence on efficacy is limited and data on safety are lacking (Rada, et al., 2010).

\section{PUBERTY INDUCTION (see also table 3).}

How should puberty be induced?

Puberty should be induced or progressed with $17 \beta$-estradiol, starting with low dose at the age of 12 with a gradual increase over 2 to 3 years (Reiter, et al., 2001, Stephure and Canadian Growth Hormone Advisory Committee, 2005, van Pareren, et al., 2003).

In cases of late diagnosis and for those girls in whom growth is not a concern, a modified regimen of estradiol can be considered (Davenport, 2008). 
Evidence for the optimum mode of administration (oral or transdermal) is inconclusive. Transdermal estradiol results in more physiological estrogen levels and is therefore preferred (Ankarberg-Lindgren, et al., 2001, Cisternino, et al., 1991, Illig, et al., 1990, Mauras, et al., 2007, Nabhan, et al., 2009, Piippo, et al., 2004, Torres-Santiago, et al., 2013).

The oral contraceptive pill is contra-indicated for puberty induction (Bondy and Turner Syndrome Study Group, 2007, Davenport, 2010).

Begin cyclical progestogens after at least 2 years of estrogen or when breakthrough bleeding occurs (Bondy and Turner Syndrome Study Group, 2007, Furness, et al., 2012).

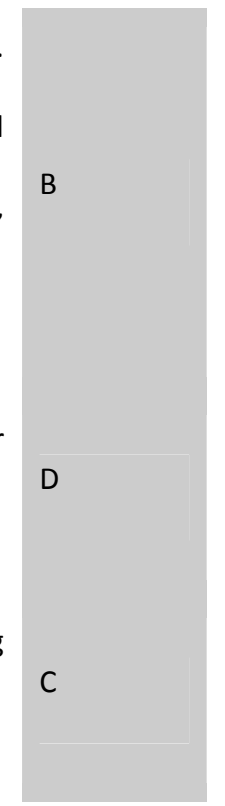




\section{Discussion}

The ESHRE guideline on the management of women with premature ovarian insufficiency comprises 95 recommendations and 4 statements on the diagnosis, sequelae and treatment of premature ovarian insufficiency. The recommendations have been formulated by a multidisciplinary group of experts based on the best available evidence, and they have been reviewed by relevant stakeholders. Based on the assessment of the current literature on POI during the development of the guideline it is clear that evidence is limited. Of the 95 recommendations, $33(34.7 \%)$ were based on expert opinion, and graded as a good practice point. Only 15 of the 31 key questions were regarding treatment and management options, while the other questions dealt with diagnosis, monitoring and sequelae of POI. From the 61 recommendations on interventions (not including monitoring), 12 (19.7\%) could be based on good quality evidence (level A or B), 35 (57.4\%) were based on moderate quality evidence (C or D), and 14 (22.9\%) were formulated as GPP.

The lack of sufficient high quality evidence on the interventions available for women was the most significant limitation for the current guideline, and has led to a number of topics for future research: (1) the accuracy of biochemical markers (e.g. FSH, $\mathrm{AMH}$ ) in the diagnosis of $\mathrm{POI},(2)$ long-term health outcomes of POI, examining contributory factors such as smoking, and the effect of long-term HRT (3) fertility treatment and associated obstetric risks in women with $\mathrm{POI}(4)$ lifetime risk of fracture in women with $\mathrm{POI}$, and the impact of interventions (5) cardiovascular risk factors in women with POI (6) impact of POI on wellbeing and quality of life, including interventions (7) comparisons of the efficacy, patient's satisfaction and side effects of the different options for HRT, and (8) the optimal approach for oncological POI patients.

One of the options explored for the collection of long-term data is a POI registry, as suggested by Panay and colleagues (Panay and Fenton, 2012).

Despite the limitations of guidelines in general, and the limitations in the evidence supporting the current guideline, the guideline group is confident that this document will help best practice in the management of women with POI. Efforts will be undertaken to ensure adequate dissemination and implementation of the guideline. 
160

161

162

163

\section{References}

Abdalla HI, Billett A, Kan AK, Baig S, Wren M, Korea L, Studd JW. Obstetric outcome in 232 ovum donation pregnancies. Br J Obstet Gynaecol 1998;105: 332-337.

Absolom K, Eiser C, Turner L, Ledger W, Ross R, Davies H, Coleman R, Hancock B, Snowden J, Greenfield D et al. Ovarian failure following cancer treatment: current management and quality of life. Human reproduction 2008;23: 2506-2512.

Albright F, Smith P, Fraser R. A syndrome characterized by primary ovarian insufficiency and decreased stature. The American journal of the medical sciences 1942;204: 625-648.

Alexander JL, Kotz K, Dennerstein L, Kutner SJ, Wallen K, Notelovitz M. The effects of postmenopausal hormone therapies on female sexual functioning: a review of double-blind, randomized controlled trials. Menopause 2004;11: 749-765.

Altena R, Gietema JA, van Veldhuisen DJ, Reyners AK. Pregnancy unbosoms the heart of breast cancer survivors. Annals of oncology : official journal of the European Society for Medical Oncology / ESMO 2012;23: 2206-2208.

Amagai Y, Ishikawa S, Gotoh T, Kayaba K, Nakamura Y, Kajii E. Age at menopause and mortality in Japan: the Jichi Medical School Cohort Study. Journal of epidemiology / Japan Epidemiological Association 2006;16: 161-166.

Ang WC, Farrell E, Vollenhoven B. Effect of hormone replacement therapies and selective estrogen receptor modulators in postmenopausal women with uterine leiomyomas: a literature review. Climacteric 2001;4: 284-292.

Ankarberg-Lindgren C, Elfving M, Wikland KA, Norjavaara E. Nocturnal application of transdermal estradiol patches produces levels of estradiol that mimic those seen at the onset of spontaneous puberty in girls. The Journal of clinical endocrinology and metabolism 2001;86: 3039-3044.

Antoine C, Liebens F, Carly B, Pastijn A, Neusy S, Rozenberg S. Safety of hormone therapy after breast cancer: a qualitative systematic review. Human reproduction 2007;22: 616-622.

Armstrong K, Schwartz JS, Randall T, Rubin SC, Weber B. Hormone replacement therapy and life expectancy after prophylactic oophorectomy in women with BRCA1/2 mutations: a decision analysis. Journal of clinical oncology : official journal of the American Society of Clinical Oncology 2004;22: 1045-1054.

Atsma F, Bartelink ML, Grobbee DE, van der Schouw YT. Postmenopausal status and early menopause as independent risk factors for cardiovascular disease: a meta-analysis. Menopause 2006;13: 265-279. 
Baba Y, Ishikawa S, Amagi Y, Kayaba K, Gotoh T, Kajii E. Premature menopause is associated with increased risk of cerebral infarction in Japanese women. Menopause 2010;17: 506-510.

Bachelot A, Rouxel A, Massin N, Dulon J, Courtillot C, Matuchansky C, Badachi Y, Fortin A, Paniel B, Lecuru F et al. Phenotyping and genetic studies of 357 consecutive patients presenting with premature ovarian failure. European journal of endocrinology / European Federation of Endocrine Societies 2009;161: 179-187.

Bakalov VK, Axelrod L, Baron J, Hanton L, Nelson LM, Reynolds JC, Hill S, Troendle J, Bondy CA. Selective reduction in cortical bone mineral density in turner syndrome independent of ovarian hormone deficiency. The Journal of clinical endocrinology and metabolism 2003;88: 5717-5722.

Bakalov VK, Vanderhoof VH, Bondy CA, Nelson LM. Adrenal antibodies detect asymptomatic auto-immune adrenal insufficiency in young women with spontaneous premature ovarian failure. Human reproduction 2002;17: 2096-2100.

Bar J, Davidi O, Goshen Y, Hod M, Yaniv I, Hirsch R. Pregnancy outcome in women treated with doxorubicin for childhood cancer. American journal of obstetrics and gynecology 2003;189: 853-857.

Bath LE, Critchley HO, Chambers SE, Anderson RA, Kelnar CJ, Wallace WH. Ovarian and uterine characteristics after total body irradiation in childhood and adolescence: response to sex steroid replacement. Br J Obstet Gynaecol 1999;106: 12651272.

Benetti-Pinto CL, Soares PM, Magna LA, Petta CA, Dos Santos CC. Breast density in women with premature ovarian failure using hormone therapy. Gynecological endocrinology : the official journal of the International Society of Gynecological Endocrinology 2008;24: 40-43.

Betterle C, Volpato M, Rees Smith B, Furmaniak J, Chen S, Greggio NA, Sanzari M, Tedesco F, Pedini B, Boscaro M et al. I. Adrenal cortex and steroid 21-hydroxylase autoantibodies in adult patients with organ-specific autoimmune diseases: markers of low progression to clinical Addison's disease. The Journal of clinical endocrinology and metabolism 1997;82: 932-938.

Boivin J. A review of psychosocial interventions in infertility. Social science \& medicine 2003;57: 2325-2341.

Bondy CA. Congenital cardiovascular disease in Turner syndrome. Congenit Heart Dis 2008;3: 2-15.

Bondy CA, Turner Syndrome Study Group. Care of girls and women with Turner syndrome: a guideline of the Turner Syndrome Study Group. The Journal of clinical endocrinology and metabolism 2007;92: 10-25. 
211

Bours SP, van Geel TA, Geusens PP, Janssen MJ, Janzing HM, Hoffland GA, Willems PC, van den Bergh JP. Contributors to secondary osteoporosis and metabolic bone diseases in patients presenting with a clinical fracture. The Journal of clinical endocrinology and metabolism 2011;96: 1360-1367.

Bove R, Secor E, Chibnik LB, Barnes LL, Schneider JA, Bennett DA, De Jager PL. Age at surgical menopause influences cognitive decline and Alzheimer pathology in older women. Neurology 2014;82: 222-229.

Bowman MC, Saunders DM. Rates of aneuploidy in oocytes of older women: are equivocal findings of concern for postmenopausal embryo recipients? Human reproduction 1994;9: 1200-1201.

Braunstein GD, Sundwall DA, Katz M, Shifren JL, Buster JE, Simon JA, Bachman G, Aguirre OA, Lucas JD, Rodenberg C et al. Safety and efficacy of a testosterone patch for the treatment of hypoactive sexual desire disorder in surgically menopausal women: a randomized, placebo-controlled trial. Archives of internal medicine 2005;165: 1582-1589.

Bryman I, Sylven L, Berntorp K, Innala E, Bergstrom I, Hanson C, Oxholm M, Landin-Wilhelmsen K. Pregnancy rate and outcome in Swedish women with Turner syndrome. Fertility and sterility 2011;95: 2507-2510.

Buster JE, Kingsberg SA, Aguirre O, Brown C, Breaux JG, Buch A, Rodenberg CA, Wekselman K, Casson P. Testosterone patch for low sexual desire in surgically menopausal women: a randomized trial. Obstetrics and gynecology 2005;105: 944-952.

Canonico M, Oger E, Conard J, Meyer G, Levesque H, Trillot N, Barrellier MT, Wahl D, Emmerich J, Scarabin PY et al. Obesity and risk of venous thromboembolism among postmenopausal women: differential impact of hormone therapy by route of estrogen administration. The ESTHER Study. Journal of thrombosis and haemostasis : JTH 2006;4: 1259-1265.

Canonico M, Plu-Bureau G, Lowe GD, Scarabin PY. Hormone replacement therapy and risk of venous thromboembolism in postmenopausal women: systematic review and meta-analysis. Bmj 2008;336: 1227-1231.

Castaneda S, Carmona L, Carvajal I, Arranz R, Diaz A, Garcia-Vadillo A. Reduction of bone mass in women after bone marrow transplantation. Calcif Tissue Int 1997;60: 343-347.

Challoumas D, Cobbold C, Dimitrakakis G. Effects of calcium intake on the cardiovascular system in postmenopausal women. Atherosclerosis 2013;231: 1-7.

Chen S, Sawicka J, Betterle C, Powell M, Prentice L, Volpato M, Rees Smith B, Furmaniak J. Autoantibodies to steroidogenic enzymes in autoimmune polyglandular syndrome, Addison's disease, and premature ovarian failure. The Journal of clinical endocrinology and metabolism 1996;81: 1871-1876. 
Ciarmela P, Ciavattini A, Giannubilo SR, Lamanna P, Fiorini R, Tranquilli AL, Christman GM, Castellucci M. Management of leiomyomas in perimenopausal women. Maturitas 2014;78: 168-173.

Cisternino M, Nahoul K, Bozzola M, Grignani G, Perani G, Sampaolo P, Roger M, Severi F. Transdermal estradiol substitution therapy for the induction of puberty in female hypogonadism. J Endocrinol Invest 1991;14: 481-488.

Conway GS, Kaltsas G, Patel A, Davies MC, Jacobs HS. Characterization of idiopathic premature ovarian failure. Fertility and sterility 1996;65: 337-341.

Cooper GS, Sandler DP. Age at natural menopause and mortality. Annals of epidemiology 1998;8: 229-235.

Crofton PM, Evans N, Bath LE, Warner P, Whitehead TJ, Critchley HO, Kelnar CJ, Wallace WH. Physiological versus standard sex steroid replacement in young women with premature ovarian failure: effects on bone mass acquisition and turnover. Clinical endocrinology 2010;73: 707-714.

Dal Pra C, Chen S, Furmaniak J, Smith BR, Pedini B, Moscon A, Zanchetta R, Betterle C. Autoantibodies to steroidogenic enzymes in patients with premature ovarian failure with and without Addison's disease. European journal of endocrinology / European Federation of Endocrine Societies 2003;148: 565-570.

Davenport ML. Moving toward an understanding of hormone replacement therapy in adolescent girls: looking through the lens of Turner syndrome. Annals of the New York Academy of Sciences 2008;1135: 126-137.

Davenport ML. Approach to the patient with Turner syndrome. The Journal of clinical endocrinology and metabolism 2010;95: 1487-1495.

Davis SR, Moreau M, Kroll R, Bouchard C, Panay N, Gass M, Braunstein GD, Hirschberg AL, Rodenberg C, Pack S et al. Testosterone for low libido in postmenopausal women not taking estrogen. The New England journal of medicine 2008;359: 2005-2017.

Davis SR, van der Mooren MJ, van Lunsen RH, Lopes P, Ribot C, Rees M, Moufarege A, Rodenberg C, Buch A, Purdie DW. Efficacy and safety of a testosterone patch for the treatment of hypoactive sexual desire disorder in surgically menopausal women: a randomized, placebo-controlled trial. Menopause 2006;13: 387-396.

de Kleijn MJ, van der Schouw YT, Verbeek AL, Peeters PH, Banga JD, van der Graaf Y. Endogenous estrogen exposure and cardiovascular mortality risk in postmenopausal women. American journal of epidemiology 2002;155: 339-345. 
Donnenfeld AE, Icke KV, Pargas C, Dowman C. Biochemical screening for aneuploidy in ovum donor pregnancies. American journal of obstetrics and gynecology 2002;187: 1222-1225.

Downey J, Elkin EJ, Ehrhardt AA, Meyer-Bahlburg HF, Bell JJ, Morishima A. Cognitive ability and everyday functioning in women with Turner syndrome. J Learn Disabil 1991;24: 32-39.

Duijts SF, van Beurden M, Oldenburg HS, Hunter MS, Kieffer JM, Stuiver MM, Gerritsma MA, Menke-Pluymers MB, Plaisier PW, Rijna $\mathrm{H}$ et al. Efficacy of cognitive behavioral therapy and physical exercise in alleviating treatment-induced menopausal symptoms in patients with breast cancer: results of a randomized, controlled, multicenter trial. Journal of clinical oncology : official journal of the American Society of Clinical Oncology 2012;30: 4124-4133.

Dunselman GA, Vermeulen N, Becker C, Calhaz-Jorge C, D'Hooghe T, De Bie B, Heikinheimo O, Horne AW, Kiesel L, Nap A et al. ESHRE guideline: management of women with endometriosis. Human reproduction 2014;29: 400-412.

Elsheikh M, Bird R, Casadei B, Conway GS, Wass JA. The effect of hormone replacement therapy on cardiovascular hemodynamics in women with Turner's syndrome. The Journal of clinical endocrinology and metabolism 2000;85: 614-618.

Felker GM, Thompson RE, Hare JM, Hruban RH, Clemetson DE, Howard DL, Baughman KL, Kasper EK. Underlying causes and long-term survival in patients with initially unexplained cardiomyopathy. The New England journal of medicine 2000;342: 1077-1084.

File SE, Heard JE, Rymer J. Trough oestradiol levels associated with cognitive impairment in post-menopausal women after 10 years of oestradiol implants. Psychopharmacology 2002;161: 107-112.

Finucane B, Abrams L, Cronister A, Archibald AD, Bennett RL, McConkie-Rosell A. Genetic counseling and testing for FMR1 gene mutations: practice guidelines of the national society of genetic counselors. Journal of genetic counseling 2012;21: 752-760.

Freriks K, Timmermans J, Beerendonk CC, Verhaak CM, Netea-Maier RT, Otten BJ, Braat DD, Smeets DF, Kunst DH, Hermus AR et al. Standardized multidisciplinary evaluation yields significant previously undiagnosed morbidity in adult women with Turner syndrome. The Journal of clinical endocrinology and metabolism 2011;96: E1517-1526.

Furness S, Roberts $\mathrm{H}$, Marjoribanks J, Lethaby A. Hormone therapy in postmenopausal women and risk of endometrial hyperplasia. Cochrane database of systematic reviews (Online) 2012;8: CD000402. 
Gallagher LG, Davis LB, Ray RM, Psaty BM, Gao DL, Checkoway H, Thomas DB. Reproductive history and mortality from cardiovascular disease among women textile workers in Shanghai, China. International journal of epidemiology 2011;40: $1510-1518$

Genetics Committee of the Society of Obstetricians and Gynaecologists of Canada, Prenatal Diagnosis Committee of the Canadian College of Medical Geneticists, Chitayat D, Wyatt PR, Wilson RD, Johnson JA, Audibert F, Allen V, Gagnon A, Langlois $\mathrm{S}$ et al. Fragile $\mathrm{X}$ testing in obstetrics and gynaecology in Canada. Journal of obstetrics and gynaecology Canada : JOGC = Journal d'obstetrique et gynecologie du Canada : JOGC 2008;30: 837-846.

Gorton H, Wilson R, Robinson A, Lyons G. Survivors of childhood cancers: implications for obstetric anaesthesia. British journal of anaesthesia 2000;85: 911-913.

Goswami R, Marwaha RK, Goswami D, Gupta N, Ray D, Tomar N, Singh S. Prevalence of thyroid autoimmunity in sporadic idiopathic hypoparathyroidism in comparison to type 1 diabetes and premature ovarian failure. The Journal of clinical endocrinology and metabolism 2006;91: 4256-4259.

Gravholt CH, Juul S, Naeraa RW, Hansen J. Morbidity in Turner syndrome. Journal of clinical epidemiology 1998;51: 147158.

Grimaldi EF, Restaino S, Inglese S, Foltran L, Sorz A, Di Lorenzo G, Guaschino S. Role of high molecular weight hyaluronic acid in postmenopausal vaginal discomfort. Minerva ginecologica 2012;64: 321-329.

Haddow JE, Palomaki GE, Allan WC, Williams JR, Knight GJ, Gagnon J, O'Heir CE, Mitchell ML, Hermos RJ, Waisbren SE et al. Maternal thyroid deficiency during pregnancy and subsequent neuropsychological development of the child. The New England journal of medicine 1999;341: 549-555.

Hadjidakis D, Kokkinakis E, Sfakianakis M, Raptis SA. The type and time of menopause as decisive factors for bone mass changes. Eur J Clin Invest 1999;29: 877-885.

Hadnott TN, Gould HN, Gharib AM, Bondy CA. Outcomes of spontaneous and assisted pregnancies in Turner syndrome: the U.S. National Institutes of Health experience. Fertility and sterility 2011;95: 2251-2256.

Hagman A, Loft A, Wennerholm UB, Pinborg A, Bergh C, Aittomaki K, Nygren KG, Bente Romundstad L, Hazekamp J, Soderstrom-Anttila V. Obstetric and neonatal outcome after oocyte donation in 106 women with Turner syndrome: a Nordic cohort study. Human reproduction 2013;28: 1598-1609. 
313

314

315

316

Han TS, Goswami D, Trikudanathan S, Creighton SM, Conway GS. Comparison of bone mineral density and body proportions between women with complete androgen insensitivity syndrome and women with gonadal dysgenesis. European journal of endocrinology / European Federation of Endocrine Societies 2008;159: 179-185.

Hogervorst E, Bandelow S. Sex steroids to maintain cognitive function in women after the menopause: a meta-analyses of treatment trials. Maturitas 2010;66: 56-71.

Hollowell JG, Staehling NW, Flanders WD, Hannon WH, Gunter EW, Spencer CA, Braverman LE. Serum TSH, T(4), and thyroid antibodies in the United States population (1988 to 1994): National Health and Nutrition Examination Survey (NHANES III). The Journal of clinical endocrinology and metabolism 2002;87: 489-499.

Hong JS, Yi SW, Kang HC, Jee SH, Kang HG, Bayasgalan G, Ohrr H. Age at menopause and cause-specific mortality in South Korean women: Kangwha Cohort Study. Maturitas 2007;56: 411-419.

Hu FB, Grodstein F, Hennekens CH, Colditz GA, Johnson M, Manson JE, Rosner B, Stampfer MJ. Age at natural menopause and risk of cardiovascular disease. Archives of internal medicine 1999;159: 1061-1066.

Husebye ES, Lovas K. Immunology of Addison's disease and premature ovarian failure. Endocrinology and metabolism clinics of North America 2009;38: 389-405, ix.

Illig R, DeCampo C, Lang-Muritano MR, Prader A, Torresani T, Werder EA, Willi U, Schenkel L. A physiological mode of puberty induction in hypogonadal girls by low dose transdermal 17 beta-oestradiol. European journal of pediatrics 1990;150: 86-91.

Jacobsen BK, Heuch I, Kvale G. Age at natural menopause and all-cause mortality: a 37-year follow-up of 19,731 Norwegian women. American journal of epidemiology 2003;157: 923-929.

Jacobsen BK, Heuch I, Kvale G. Age at natural menopause and stroke mortality: cohort study with 3561 stroke deaths during 37-year follow-up. Stroke; a journal of cerebral circulation 2004;35: 1548-1551.

Jacobsen BK, Knutsen SF, Fraser GE. Age at natural menopause and total mortality and mortality from ischemic heart disease: the Adventist Health Study. Journal of clinical epidemiology 1999;52: 303-307.

Jiao X, Qin C, Li J, Qin Y, Gao X, Zhang B, Zhen X, Feng Y, Simpson JL, Chen ZJ. Cytogenetic analysis of 531 Chinese women with premature ovarian failure. Human reproduction 2012;27: 2201-2207. 
Kalantari H, Madani T, Zari Moradi S, Mansouri Z, Almadani N, Gourabi H, Mohseni Meybodi A. Cytogenetic analysis of 179 Iranian women with premature ovarian failure. Gynecological endocrinology : the official journal of the International Society of Gynecological Endocrinology 2013;29: 588-591.

Kalantaridou SN, Naka KK, Papanikolaou E, Kazakos N, Kravariti M, Calis KA, Paraskevaidis EA, Sideris DA, Tsatsoulis A, Chrousos GP et al. Impaired endothelial function in young women with premature ovarian failure: normalization with hormone therapy. The Journal of clinical endocrinology and metabolism 2004;89: 3907-3913.

Kanis JA, McCloskey EV, Johansson H, Cooper C, Rizzoli R, Reginster JY, Scientific Advisory Board of the European Society for C, Economic Aspects of O, Osteoarthritis, the Committee of Scientific Advisors of the International Osteoporosis F. European guidance for the diagnosis and management of osteoporosis in postmenopausal women. Osteoporos Int 2013;24: 23-57.

Karnis MF. Catastrophic consequences of assisted reproduction: the case of Turner syndrome. Seminars in reproductive medicine 2012;30: 116-122.

Khastgir G, Studd JW, Fox SW, Jones J, Alaghband-Zadeh J, Chow JW. A longitudinal study of the effect of subcutaneous estrogen replacement on bone in young women with Turner's syndrome. Journal of bone and mineral research : the official journal of the American Society for Bone and Mineral Research 2003;18: 925-932.

Kim TJ, Anasti JN, Flack MR, Kimzey LM, Defensor RA, Nelson LM. Routine endocrine screening for patients with karyotypically normal spontaneous premature ovarian failure. Obstetrics and gynecology 1997;89: 777-779.

Kingsberg SA, Simon JA, Goldstein I. The current outlook for testosterone in the management of hypoactive sexual desire disorder in postmenopausal women. The journal of sexual medicine 2008;5 Suppl 4: 182-193; quiz 193.

Kodama M, Komura H, Kodama T, Nishio Y, Kimura T. Estrogen therapy initiated at an early age increases bone mineral density in Turner syndrome patients. Endocrine journal 2012;59: 153-159.

Kokcu A. Premature ovarian failure from current perspective. Gynecological endocrinology : the official journal of the International Society of Gynecological Endocrinology 2010;26: 555-562.

Kritz-Silverstein D, Barrett-Connor E. Hysterectomy, oophorectomy, and cognitive function in older women. Journal of the American Geriatrics Society 2002;50: 55-61. 
363 364 365

Langrish JP, Mills NL, Bath LE, Warner P, Webb DJ, Kelnar CJ, Critchley HO, Newby DE, Wallace WH. Cardiovascular effects of physiological and standard sex steroid replacement regimens in premature ovarian failure. Hypertension 2009;53: 805811.

Larsen EC, Schmiegelow K, Rechnitzer C, Loft A, Muller J, Andersen AN. Radiotherapy at a young age reduces uterine volume of childhood cancer survivors. Acta obstetricia et gynecologica Scandinavica 2004;83: 96-102.

Le Donne M, Caruso C, Mancuso A, Costa G, lemmo R, Pizzimenti G, Cavallari V. The effect of vaginally administered genistein in comparison with hyaluronic acid on atrophic epithelium in postmenopause. Archives of gynecology and obstetrics 2011;283: 1319-1323.

Liao KL, Wood N, Conway GS. Premature menopause and psychological well-being. Journal of psychosomatic obstetrics and gynaecology 2000;21: 167-174.

Lindsay R, Hart DM, Forrest C, Baird C. Prevention of spinal osteoporosis in oophorectomised women. Lancet 1980;2: 11511154.

Lobo RA. Absorption and metabolic effects of different types of estrogens and progestogens. Obstetrics and gynecology clinics of North America 1987;14: 143-167.

Lokkegaard E, Jovanovic Z, Heitmann BL, Keiding N, Ottesen B, Pedersen AT. The association between early menopause and risk of ischaemic heart disease: influence of Hormone Therapy. Maturitas 2006;53: 226-233.

Madalinska JB, van Beurden M, Bleiker EM, Valdimarsdottir HB, Hollenstein J, Massuger LF, Gaarenstroom KN, Mourits MJ, Verheijen $\mathrm{RH}$, van Dorst EB et al. The impact of hormone replacement therapy on menopausal symptoms in younger highrisk women after prophylactic salpingo-oophorectomy. Journal of clinical oncology : official journal of the American Society of Clinical Oncology 2006;24: 3576-3582.

Mann E, Singer D, Pitkin J, Panay N, Hunter MS. Psychosocial adjustment in women with premature menopause: a crosssectional survey. Climacteric 2012;15: 481-489.

Mann E, Smith MJ, Hellier J, Balabanovic JA, Hamed H, Grunfeld EA, Hunter MS. Cognitive behavioural treatment for women who have menopausal symptoms after breast cancer treatment (MENOS 1): a randomised controlled trial. The lancet oncology 2012;13: 309-318. 
Mauras N, Shulman D, Hsiang HY, Balagopal P, Welch S. Metabolic effects of oral versus transdermal estrogen in growth hormone-treated girls with turner syndrome. The Journal of clinical endocrinology and metabolism 2007;92: 4154-4160.

Michala L, Goswami D, Creighton SM, Conway GS. Swyer syndrome: presentation and outcomes. BJOG 2008;115: 737-741.

Mondul AM, Rodriguez C, Jacobs EJ, Calle EE. Age at natural menopause and cause-specific mortality. American journal of epidemiology 2005;162: 1089-1097.

Mortensen KH, Hansen KW, Erlandsen M, Christiansen JS, Gravholt CH. Ambulatory arterial stiffness index in Turner syndrome: the impact of sex hormone replacement therapy. Hormone research 2009;72: 184-189.

Mulrooney DA, Yeazel MW, Kawashima T, Mertens AC, Mitby P, Stovall M, Donaldson SS, Green DM, Sklar CA, Robison LL et al. Cardiac outcomes in a cohort of adult survivors of childhood and adolescent cancer: retrospective analysis of the Childhood Cancer Survivor Study cohort. Bmj 2009;339: b4606.

Nabhan ZM, Dimeglio LA, Qi R, Perkins SM, Eugster EA. Conjugated oral versus transdermal estrogen replacement in girls with Turner syndrome: a pilot comparative study. The Journal of clinical endocrinology and metabolism 2009;94: 20092014.

Nappi RE, Cagnacci A, Granella F, Piccinini F, Polatti F, Facchinetti F. Course of primary headaches during hormone replacement therapy. Maturitas 2001;38: 157-163.

Nelson SM, Lawlor DA. Predicting live birth, preterm delivery, and low birth weight in infants born from in vitro fertilisation: a prospective study of 144,018 treatment cycles. PLoS medicine 2011;8: e1000386.

Ossewaarde ME, Bots ML, Verbeek AL, Peeters PH, van der Graaf Y, Grobbee DE, van der Schouw YT. Age at menopause, cause-specific mortality and total life expectancy. Epidemiology (Cambridge, Mass) 2005;16: 556-562.

Ostberg JE, Storry C, Donald AE, Attar MJ, Halcox JP, Conway GS. A dose-response study of hormone replacement in young hypogonadal women: effects on intima media thickness and metabolism. Clinical endocrinology 2007;66: 557-564.

Oyesanya OA, Olufowobi O, Ross W, Sharif K, Afnan M. Prognosis of oocyte donation cycles: a prospective comparison of the in vitro fertilization-embryo transfer cycles of recipients who used shared oocytes versus those who used altruistic donors. Fertility and sterility 2009;92: 930-936.

Pacello PC, Yela DA, Rabelo S, Giraldo PC, Benetti-Pinto CL. Dyspareunia and lubrication in premature ovarian failure using hormonal therapy and vaginal health. Climacteric 2013. 
414

415

416

417

Pados G, Camus M, Van Steirteghem A, Bonduelle M, Devroey P. The evolution and outcome of pregnancies from oocyte donation. Human reproduction 1994;9: 538-542.

Panay N, Al-Azzawi F, Bouchard C, Davis SR, Eden J, Lodhi I, Rees M, Rodenberg CA, Rymer J, Schwenkhagen A et al. Testosterone treatment of HSDD in naturally menopausal women: the ADORE study. Climacteric 2010;13: 121-131.

Panay N, Fenton A. Premature ovarian insufficiency: working towards an international database. Climacteric 2012;15: 295296.

Park KH, Lee SJ, Kim JY, Kim JY, Bai SW, Kim JW. A concomitant decrease in cortical and trabecular bone mass in isolated hypogonadotropic hypogonadism and gonadal dysgenesis. Yonsei medical journal 1999;40: 444-449.

Perk J, De Backer G, Gohlke H, Graham I, Reiner Z, Verschuren WM, Albus C, Benlian P, Boysen G, Cifkova R et al. European guidelines on cardiovascular disease prevention in clinical practice (version 2012) : the fifth joint task force of the European society of cardiology and other societies on cardiovascular disease prevention in clinical practice (constituted by representatives of nine societies and by invited experts). Int J Behav Med 2012;19: 403-488.

Phillips SM, Sherwin BB. Effects of estrogen on memory function in surgically menopausal women. Psychoneuroendocrinology 1992;17: 485-495.

Phung TK, Waltoft BL, Laursen TM, Settnes A, Kessing LV, Mortensen PB, Waldemar G. Hysterectomy, oophorectomy and risk of dementia: a nationwide historical cohort study. Dementia and geriatric cognitive disorders 2010;30: 43-50.

Piccioni P, Scirpa P, D'Emilio I, Sora F, Scarciglia M, Laurenti L, De Matteis S, Sica S, Leone G, Chiusolo P. Hormonal replacement therapy after stem cell transplantation. Maturitas 2004;49: 327-333.

Piippo S, Lenko H, Kainulainen P, Sipila I. Use of percutaneous estrogen gel for induction of puberty in girls with Turner syndrome. The Journal of clinical endocrinology and metabolism 2004;89: 3241-3247.

Popat VB, Calis KA, Vanderhoof VH, Cizza G, Reynolds JC, Sebring N, Troendle JF, Nelson LM. Bone mineral density in estrogen-deficient young women. The Journal of clinical endocrinology and metabolism 2009;94: 2277-2283.

Prior JC, Vigna YM, Wark JD, Eyre DR, Lentle BC, Li DK, Ebeling PR, Atley L. Premenopausal ovariectomy-related bone loss: a randomized, double-blind, one-year trial of conjugated estrogen or medroxyprogesterone acetate. Journal of bone and mineral research : the official journal of the American Society for Bone and Mineral Research 1997;12: 1851-1863. 
Rada G, Capurro D, Pantoja T, Corbalán J, Moreno G, Letelier Luz M, Vera C. Non-hormonal interventions for hot flushes in women with a history of breast cancer Cochrane Database of Systematic Reviews. 2010. John Wiley \& Sons, Ltd.

Ratcliffe MA, Lanham SA, Reid DM, Dawson AA. Bone mineral density (BMD) in patients with lymphoma: the effects of chemotherapy, intermittent corticosteroids and premature menopause. Hematological oncology 1992;10: 181-187.

Rebbeck TR, Friebel T, Wagner T, Lynch HT, Garber JE, Daly MB, Isaacs C, Olopade OI, Neuhausen SL, van 't Veer Let al. Effect of short-term hormone replacement therapy on breast cancer risk reduction after bilateral prophylactic oophorectomy in BRCA1 and BRCA2 mutation carriers: the PROSE Study Group. Journal of clinical oncology : official journal of the American Society of Clinical Oncology 2005;23: 7804-7810.

Reiter EO, Blethen SL, Baptista J, Price L. Early initiation of growth hormone treatment allows age-appropriate estrogen use in Turner's syndrome. The Journal of clinical endocrinology and metabolism 2001;86: 1936-1941.

Rocca WA, Bower JH, Maraganore DM, Ahlskog JE, Grossardt BR, de Andrade M, Melton L, 3rd. Increased risk of cognitive impairment or dementia in women who underwent oophorectomy before menopause. Neurology 2007;69: 1074-1083.

Rocca WA, Bower JH, Maraganore DM, Ahlskog JE, Grossardt BR, de Andrade M, Melton LJ, 3rd. Increased risk of parkinsonism in women who underwent oophorectomy before menopause. Neurology 2008;70: 200-209.

Rocca WA, Grossardt BR, de Andrade M, Malkasian GD, Melton LJ, 3rd. Survival patterns after oophorectomy in premenopausal women: a population-based cohort study. The lancet oncology 2006;7: 821-828.

Rocha VB, Guerra-Junior G, Marques-de-Faria AP, de Mello MP, Maciel-Guerra AT. Complete gonadal dysgenesis in clinical practice: the 46,XY karyotype accounts for more than one third of cases. Fertility and sterility 2011;96: 1431-1434.

Romans SM, Stefanatos G, Roeltgen DP, Kushner H, Ross JL. Transition to young adulthood in Ullrich-Turner syndrome: neurodevelopmental changes. American journal of medical genetics 1998;79: 140-147.

Ross JL, Roeltgen D, Feuillan P, Kushner H, Cutler GB, Jr. Effects of estrogen on nonverbal processing speed and motor function in girls with Turner's syndrome. The Journal of clinical endocrinology and metabolism 1998;83: 3198-3204.

Rubinow DR, Schmidt PJ, Roca CA. Estrogen-serotonin interactions: implications for affective regulation. Biol Psychiatry 1998;44: 839-850.

Sarrel PM. Sexuality in the middle years. Obstetrics and gynecology clinics of North America 1987;14: 49-62. 
464

465

466

467

468

Sauer MV, Paulson RJ, Ary BA, Lobo RA. Three hundred cycles of oocyte donation at the University of Southern California: assessing the effect of age and infertility diagnosis on pregnancy and implantation rates. Journal of assisted reproduction and genetics 1994;11: 92-96.

Schmidt PJ, Luff JA, Haq NA, Vanderhoof VH, Koziol DE, Calis KA, Rubinow DR, Nelson LM. Depression in women with spontaneous 46, XX primary ovarian insufficiency. The Journal of clinical endocrinology and metabolism 2011;96: E278-287.

Scottish Intercollegiate Guidelines Network (SIGN). Long term follow up of survivors of childhood cancer. Edinburgh: SIGN; 2013

(SIGN publication no 132) 2013;Available from URL: http://www.sign.ac.uk.

Shapiro CL, Halabi S, Hars V, Archer L, Weckstein D, Kirshner J, Sikov W, Winer E, Burstein HJ, Hudis C et al. Zoledronic acid preserves bone mineral density in premenopausal women who develop ovarian failure due to adjuvant chemotherapy: final results from CALGB trial 79809. European journal of cancer 2011;47: 683-689.

Sharma J, Friedman D, Dave-Sharma S, Harbison M. Aortic distensibility and dilation in Turner's syndrome. Cardiol Young 2009;19: 568-572.

Sherwin BB. Estrogen and/or androgen replacement therapy and cognitive functioning in surgically menopausal women. Psychoneuroendocrinology 1988;13: 345-357.

Sherwin BB. Estrogenic effects on memory in women. Annals of the New York Academy of Sciences 1994;743: 213-230; discussion 230-211.

Shifren JL, Braunstein GD, Simon JA, Casson PR, Buster JE, Redmond GP, Burki RE, Ginsburg ES, Rosen RC, Leiblum SR et al. Transdermal testosterone treatment in women with impaired sexual function after oophorectomy. The New England journal of medicine 2000;343: 682-688.

Signorello LB, Mulvihill JJ, Green DM, Munro HM, Stovall M, Weathers RE, Mertens AC, Whitton JA, Robison LL, Boice JD, Jr. Stillbirth and neonatal death in relation to radiation exposure before conception: a retrospective cohort study. Lancet 2010;376: 624-630.

Signorello LB, Mulvihill JJ, Green DM, Munro HM, Stovall M, Weathers RE, Mertens AC, Whitton JA, Robison LL, Boice JD, Jr. Congenital anomalies in the children of cancer survivors: a report from the childhood cancer survivor study. Journal of clinical oncology : official journal of the American Society of Clinical Oncology 2012;30: 239-245. 
Simon J, Braunstein G, Nachtigall L, Utian W, Katz M, Miller S, Waldbaum A, Bouchard C, Derzko C, Buch A et al. Testosterone patch increases sexual activity and desire in surgically menopausal women with hypoactive sexual desire disorder. The Journal of clinical endocrinology and metabolism 2005;90: 5226-5233.

Soares PM, Cabello C, Magna LA, Tinois E, Benetti-Pinto CL. Breast density in women with premature ovarian failure or postmenopausal women using hormone therapy: analytical cross-sectional study. Sao Paulo medical journal = Revista paulista de medicina 2010;128: 211-214.

Soderstrom-Anttila V, Tiitinen A, Foudila T, Hovatta O. Obstetric and perinatal outcome after oocyte donation: comparison with in-vitro fertilization pregnancies. Human reproduction 1998;13: 483-490.

Stephure DK, Canadian Growth Hormone Advisory Committee. Impact of growth hormone supplementation on adult height in turner syndrome: results of the Canadian randomized controlled trial. The Journal of clinical endocrinology and metabolism 2005;90: 3360-3366.

Stevenson M, Jones ML, De Nigris E, Brewer N, Davis S, Oakley J. A systematic review and economic evaluation of alendronate, etidronate, risedronate, raloxifene and teriparatide for the prevention and treatment of postmenopausal osteoporosis. Health Technol Assess 2005;9: 1-160.

Stoop D, Baumgarten M, Haentjens P, Polyzos NP, De Vos M, Verheyen G, Camus M, Devroey P. Obstetric outcome in donor oocyte pregnancies: a matched-pair analysis. Reproductive biology and endocrinology : RB\&E 2012;10: 42.

Suckling J, Lethaby A, Kennedy R. Local oestrogen for vaginal atrophy in postmenopausal women. Cochrane database of systematic reviews (Online) 2006: CD001500.

Sung L, Bustillo M, Mukherjee T, Booth G, Karstaedt A, Copperman AB. Sisters of women with premature ovarian failure may not be ideal ovum donors. Fertility and sterility 1997;67: 912-916.

Swillen A, Fryns JP, Kleczkowska A, Massa G, Vanderschueren-Lodeweyckx M, Van den Berghe H. Intelligence, behaviour and psychosocial development in Turner syndrome. A cross-sectional study of 50 pre-adolescent and adolescent girls (4-20 years). Genetic counseling (Geneva, Switzerland) 1993;4: 7-18.

Tamimi RM, Hankinson SE, Chen WY, Rosner B, Colditz GA. Combined estrogen and testosterone use and risk of breast cancer in postmenopausal women. Archives of internal medicine 2006;166: 1483-1489. 
515

516

517

518

519

Templeton A, Morris JK, Parslow W. Factors that affect outcome of in-vitro fertilisation treatment. Lancet 1996;348: 1402 1406.

Torres-Santiago L, Mericq V, Taboada M, Unanue N, Klein KO, Singh R, Hossain J, Santen RJ, Ross JL, Mauras N. Metabolic effects of oral versus transdermal 17beta-estradiol $(E(2))$ : a randomized clinical trial in girls with Turner syndrome. The Journal of clinical endocrinology and metabolism 2013;98: 2716-2724.

van Dalen EC, van der Pal HJ, van den Bos C, Kok WE, Caron HN, Kremer LC. Clinical heart failure during pregnancy and delivery in a cohort of female childhood cancer survivors treated with anthracyclines. European journal of cancer 2006;42: 2549-2553.

van der Schouw YT, van der Graaf Y, Steyerberg EW, Eijkemans JC, Banga JD. Age at menopause as a risk factor for cardiovascular mortality. Lancet 1996;347: 714-718.

van Kasteren YM, Schoemaker J. Premature ovarian failure: a systematic review on therapeutic interventions to restore ovarian function and achieve pregnancy. Human reproduction update 1999;5: 483-492.

van Pareren YK, de Muinck Keizer-Schrama SM, Stijnen T, Sas TC, Jansen M, Otten BJ, Hoorweg-Nijman JJ, Vulsma T, Stokvis-Brantsma $\mathrm{WH}$, Rouwe $\mathrm{CW}$ et al. Final height in girls with turner syndrome after long-term growth hormone treatment in three dosages and low dose estrogens. The Journal of clinical endocrinology and metabolism 2003;88: 11191125.

Vearncombe KJ, Pachana NA. Is cognitive functioning detrimentally affected after early, induced menopause? Menopause 2009;16: 188-198.

Vermeulen N, D'Angelo A, de Sutter P, Nelen WLDM. Manual for ESHRE Guideline Development 2014, www.eshre.eu.

White WB. Drospirenone with 17beta-estradiol in the postmenopausal woman with hypertension. Climacteric 2007;10 Suppl 1: 25-31.

Wo JY, Viswanathan AN. Impact of radiotherapy on fertility, pregnancy, and neonatal outcomes in female cancer patients. International journal of radiation oncology, biology, physics 2009;73: 1304-1312.

Wu X, Cai H, Kallianpur A, Li H, Yang G, Gao J, Xiang YB, Ji BT, Yu T, Zheng W et al. Impact of Premature Ovarian Failure on Mortality and Morbidity among Chinese Women. PloS one 2014;9: e89597. 
Table 1

Interpretation on the grades of recommendations (Vermeulen, et al., 2014)

\begin{tabular}{|c|c|}
\hline Grades of & Supporting evidence \\
\hline A & Meta-analysis, systematic review or multiple randomized controlled \\
\hline & trials (RCTs) (high quality) \\
\hline B & Meta-analysis, systematic review or multiple RCTs (moderate quality) \\
& Single RCT, large non-randomized trial, case-control or cohort studies \\
& (high quality) \\
\hline C & Single RCT, large non-randomized trial, case-control or cohort studies \\
& (moderate quality) \\
\hline DPP & Non-analytical studies, case reports or case series (high or moderate \\
& Euality) \\
\hline & \\
\hline &
\end{tabular}

The grades of the recommendations is only based on the strength of the supporting evidence. In formulating strong or weak recommendations, the guideline group took the strength of the supporting evidence into account, but weight it against the benefits and harms, and the preferences of clinicians and patients. 
Table 2

Summary of diagnostic workup

\begin{tabular}{|c|c|c|}
\hline \multirow[t]{2}{*}{ Test } & \multicolumn{2}{|c|}{ Implications } \\
\hline & Positive test & Negative test \\
\hline \multicolumn{3}{|l|}{ Genetic/Chromosomal } \\
\hline $\begin{array}{l}\text { Karyotyping } \\
\text { (for diagnosis of Turner syndrome) }\end{array}$ & $\begin{array}{l}\text { Refer to endocrinologist, } \\
\text { cardiologist and geneticist }\end{array}$ & $\begin{array}{l}\text { a second analysis of the } \\
\text { karyotype in epithelial cells (in } \\
\text { case of high clinical suspicion) }\end{array}$ \\
\hline $\begin{array}{l}\text { Test for Y-chromosomal } \\
\text { material }\end{array}$ & $\begin{array}{l}\text { Discuss gonadectomy with the } \\
\text { patient }\end{array}$ & \\
\hline Fra-X & Refer to geneticist & \\
\hline \multicolumn{3}{|l|}{ Autosomal genetic testing $^{a}$} \\
\hline \multicolumn{3}{|l|}{ Antibodies $^{b}$} \\
\hline ACA/210H antibodies & Refer to endocrinologist & Re-test in case of clinical signs \\
\hline TPO-Ab & Test TSH every year & or symptoms \\
\hline
\end{tabular}


Table 3

Estrogen substitution therapy in adolescence ladapted from (Bondy and Turner Syndrome Study Group, 2007))

Age Age-specific suggestions Preparation/dose/comments

\begin{tabular}{|c|c|c|}
\hline $12-13$ years & $\begin{array}{l}\text { If no spontaneous development and } \\
\text { FSH elevated, start low dose estrogens }\end{array}$ & $\begin{array}{l}\text { 17ß-estradiol (E2) } \\
\text { Transdermal: } 6.25 \mu \mathrm{g} / \text { day }^{\mathrm{a}} \text { E2 via patch } \\
\text { Oral micronized E2: } 5 \mu \mathrm{g} / \mathrm{kg} / \text { day or } 0.25 \\
\mathrm{mg} / \text { day }\end{array}$ \\
\hline 12.5 - 15 years & $\begin{array}{l}\text { Gradually increase E2 dose at 6-12 } \\
\text { months interval over } 2 \text { - } 3 \text { years }^{\text {b }} \text { to }\end{array}$ & $\begin{array}{l}\text { Transdermal E2: } 12.5,25,37.5,50,75 \text {, } \\
\text { 100 } \mu \mathrm{g} / \text { day. (Adult dose: } 100-200 \mu \mathrm{g} / \text { day) }\end{array}$ \\
\hline & adult dose & Oral E2: 5, 7.5, 10, $15 \mu \mathrm{g} / \mathrm{kg} /$ day. \\
\hline
\end{tabular}

(Adult dose: $2-4 \mathrm{mg} /$ day)

\begin{tabular}{l|l|}
\hline $\begin{array}{l}\text { 14-16 years } \\
\text { of estrogen or when breakthrough }\end{array}$ & $\mathrm{mg} /$ day or dydrogesterone $5-10 \mathrm{mg} / \mathrm{day}$ \\
bleeding occurs & during $12-14$ days of the month ${ }^{c}$
\end{tabular}

${ }^{a}$ the lowest dose commercially available E2 transdermal patches deliver 25 or $50 \mu \mathrm{g} /$ day; it is not established whether various means of dose fractionation (e.g., administering 1/8, 1/6, 1/4 patch overnight or daily or administering whole patches for 7-10 days per month) are equivalent.

${ }^{\mathrm{b}}$ with concomitant GH therapy in Turner Syndrome, to achieve an optimal adult height the increase in E2 dose might be relatively slow; while in cases of late diagnosis and for those girls in whom growth is not a consideration, E2 may be started at somewhat higher doses and escalated more rapidly.

${ }^{\mathrm{c}}$ for prolonged treatment progesterone, dydrogesterone or medroxyprogesterone are preferred to other progestogens because of their less negative effect on lipid metabolism and less androgenic effects (Lobo, 1987). 